\title{
2'-O-[2-(Methylthio)ethyl]-Modified Oligonucleotide: An Analogue of 2'-O-[2-(Methoxy)-ethyl]-Modified Oligonucleotide with Improved Protein Binding Properties and High Binding Affinity to Target RNA ${ }^{\dagger}$
}

\author{
Thazha P. Prakash, ${ }^{\ddagger}$ Muthiah Manoharan, ${ }^{*}$, Andrew M. Kawasaki,,${ }^{\ddagger}$ Allister S. Fraser, ${ }^{\ddagger}$ Elena A. Lesnik, \\ Namir Sioufi, ${ }^{\ddagger}$ Janet M. Leeds, ${ }^{\ddagger}$ Marianna Teplova, ${ }^{\S}$ and Martin Egli ${ }^{\S}$ \\ Department of Medicinal Chemistry, Isis Pharmaceuticals, 2292 Faraday Ave, Carlsbad, California 92008, and \\ Department of Biological Sciences, Vanderbilt University, Nashville, Tennessee 37235
}

Received April 5, 2002; Revised Manuscript Received July 10, 2002

\begin{abstract}
A novel 2'-modification, 2'-O-[2-(methylthio)ethyl] or 2'-O-MTE, has been incorporated into oligonucleotides and evaluated for properties relevant to antisense activity. The results were compared with the previously characterized 2'-O-[2-(methoxy)ethyl] 2'-O-MOE modification. As expected, the 2'$O$-MTE modified oligonucleotides exhibited improved binding to human serum albumin compared to the $2^{\prime}-O$-MOE modified oligonucleotides. The $2^{\prime}-O$-MTE oligonucleotides maintained high binding affinity to target RNA. Nuclease digestion of 2'-O-MTE oligonucleotides showed that they have limited resistance to exonuclease degradation. We analyzed the crystal structure of a decamer DNA duplex containing the $2^{\prime}$-O-MTE modifcation. Analysis of the crystal structure provides insight into the improved RNA binding affinity, protein binding affinity and limited resistance of 2'-O-MTE modified oligonucleotides to exonuclease degradation.
\end{abstract}

Many 2'-modified oligonucleotides have been designed and synthesized for use in antisense technology based drug discovery. A number of these $2^{\prime}$-modifications exhibit high binding affinity to target RNA, enhanced chemical stability, and nuclease resistance and increased lipophilicity. Oligonucleotides with the $2^{\prime}-O-\left[2-\left(\right.\right.$ methoxy)ethyl] $\left(2^{\prime}-O-\mathrm{MOE}\right)^{1}$ modification (Figure 1) are among the best characterized, both with respect to biophysical properties and biological activity. The $2^{\prime}-O-M O E(1)$ modified oligonucleotide offers a $2{ }^{\circ} \mathrm{C}$ increase in melting temperature $(\mathrm{Tm}) /$ modification as a diester $\left(2^{\prime}-O-\mathrm{MOE} / \mathrm{P}=\mathrm{O}\right)$ compared to $2^{\prime}$-deoxyphosphorothioate $\left(2^{\prime}-\mathrm{H} / \mathrm{P}=\mathrm{S}\right)$ compounds with identical base composition. All $2^{\prime}$-modifications with high binding affinity to

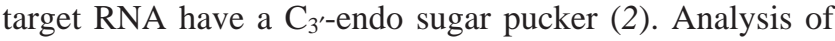

\footnotetext{
Supported by NIH Grant GM-55237. Use of the Advanced Photon Source was supported by the U.S. Department of Energy, Basic Energy Sciences, Office of Science, under Contract No. W-31-109-Eng-38. The DuPont-Northwestern-Dow Collaborative Access Team (DND-CAT) Synchrotron Research Center at the Advanced Photon Source (Sector 5) is supported by E. I. DuPont de Nemours \& Co., The Dow Chemical Company, the National Science Foundation, and the State of Illinois.

* Corresponding author. Phone: +1 (760) 603 2381. Fax: +1 (760) 603 4654. email: mmanoharan@isisph.com.

¥ Isis Pharmaceuticals.

$\S$ Vanderbilt University.

${ }^{1}$ Abbreviations: 2'-O-MTE, 2'-O-[2-(methylthio)ethyl]; 2'-O-MOE, $2^{\prime}-O$-[2-(methoxy)ethyl], HAS, human serum albumin; $\mathrm{P}=\mathrm{O}$, phosphodiester; $\mathrm{P}=\mathrm{S}$, phosphorothioate; DMF, $N, N$-dimethylformamide; $\mathrm{MeOH}$, methanol; EtOH, ethanol; DMTCl, 4,4'-dimethoxytrityl chloride; TLC, thin-layer chromatography; SVDP, snake venom phosphodiesterase; HRMS, high-resolution mass spectrum; DMAP, 4-(dimethylamino)pyridine; LCAA-CPG, long chain alkylamine controlled pore glass; TEAAc, triethylammonium acetate; HPLC, high performance liquid chromatography; CGE, capillary gel electrophoresis; Tris- $\mathrm{HCl}$, tris(hydroxymethyl)aminoethane hydrochloride; TEA, triethylamine; MPD, 2-methyl-2,4-pentanediol.
}

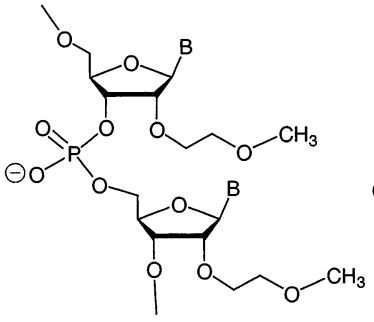

2'-O-MOE: 2'-O-[2-(methoxy)ethyl)-RNA

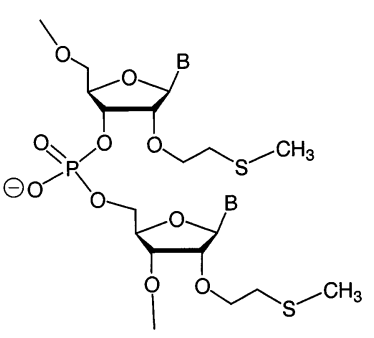

2'-O-MTE: 2'-O-[2-(methylthio)ethyl]-RNA
FIGURE 1:

digestion of oligonucleotides with snake venom phosphodiesterase has proven to be a reliable indicator of stability of the oligonucleotides in cells and in vivo (3). The 2'-O-MOE modified oligonucleotide phosphodiesters exhibits nuclease resistance (measured as the half-life of the full-length oligonucleotide, $t_{1 / 2}$ ) at approximately the same level as that of a 2'-deoxy oligonucleotide phosphorothioate of the same length and base composition.

Although phosphorothioate antisense oliogonucleotides have shown clinical promise (4-7), they have certain undesirable properties. Because of the negative charge delocalization at the internucleotide thioate bond, phosphorothioate oligonucleotides bind nonspecifically to many proteins $(8)$ and inhibit a variety of enzymes in vitro (911), perhaps leading to clinical side-effects. In contrast to other proteins, the micromolar affinity with which phosphorothioate oligonucleotides bind to human serum albumin (HSA) is actually an advantage. HSA plays a crucial role in in vivo distribution and hence pharmacokinetic properties of drugs. Human serum albumin (HSA) in blood plasma binds many endogenous and exogeneous compounds with 
association constants in the range of $10^{4}-10^{6} \mathrm{M}^{-1}$. As the most abundant protein in plasma $\left(35-50 \mathrm{mg} \mathrm{mL}^{-1}\right)$, it plays an important role in the maintenance of blood $\mathrm{pH}$ and is the most important drug carrier in the plasma. The extent of binding of antisense oligonucleotides to human serum albumin determines distribution to all target tissues of interest and therefore the in vivo pharmacokinetic properties. In contrast to $2^{\prime}$-deoxyoligonucleotide phosphorothioates $(\mathrm{P}=$ $\mathrm{S}$ ), those with $2^{\prime}-O$-MOE modified oligonucleotide phosphodiesters $(\mathrm{P}=\mathrm{O})$ are distributed primarily to the kidney and are rapidly excreted (12). To improve the pharmacokinetic and biodistribution properties of 2'-O-MOE modified oligonucleotide phosphodiesters, we have synthesized 2'-O[(2-methylthio)ethyl] or 2'-O-MTE (Figure 1) modified oligonucleotides and evaluated properties relevant to antisense activity, including affinity toward target RNA, nuclease stability, and binding to human serum albumin. Results of these biophysical measurements are interpreted using data from a crystal structure of an oligonucleotide containing a 2'-O-MTE residue.

\section{MATERIALS AND METHODS}

$N^{3}-[($ Phenylmethoxy $)$ methyl $]-2$-O-[(2-sulfooxy)ethyl]monosodiumsalt-5-methyluridine (2). $N^{3}$-[(Phenylmethoxy)methyl]5-methyluridine 1 (41.57 g, $110 \mathrm{mmol})$ was dissolved in anhydrous DMF $(250 \mathrm{~mL})$ and cooled to $-45^{\circ} \mathrm{C}$. To this $\mathrm{NaH}(4.8 \mathrm{~g}, 121 \mathrm{mmol})$ was added in three portions, and the solution was warmed to $0{ }^{\circ} \mathrm{C}$ for $1 \mathrm{~h}$. The solution was cooled to $-45^{\circ} \mathrm{C}$, and solid 1,3,2-dioxathiolane 2,2-dioxide $(15 \mathrm{~g}, 121 \mathrm{mmol})$ was added. The solution was allowed to warm to room temperature. After $5 \mathrm{~h}$ the solvent was removed under reduced pressure, and the residue was purified by silica gel column chromatography and eluted with a gradient of 5-10\% methanol in dichloromethane to give $\mathbf{2}$ $(25.60 \mathrm{~g}, 44 \%)$ as its sodium salt. The sulfates were produced in a $4: 1$ ratio as the $2^{\prime}$ and $3^{\prime}$ alkylated products. $2 \mathrm{D}^{1} \mathrm{H}$ NMR TOCSY was used to identify isomers. ${ }^{1} \mathrm{H}$ NMR (DMSO- $d_{6}$ ) $\delta 1.81(\mathrm{~s}, 3 \mathrm{H}), 3.55-3.78(\mathrm{~m}, 6 \mathrm{H}), 3.88(\mathrm{~m}, 1 \mathrm{H}), 3.96(\mathrm{~m}$, $1 \mathrm{H}), 4.13(\mathrm{~m}, 1 \mathrm{H}), 4.59(\mathrm{~s}, 2 \mathrm{H}), 5.08(\mathrm{~d}, J=5.4 \mathrm{~Hz} 1 \mathrm{H})$, $5.10(\mathrm{t}, J=6.3 \mathrm{~Hz}, 1 \mathrm{H}), 5.36(\mathrm{~s}, 2 \mathrm{H}), 5.84(\mathrm{~d}, 1 \mathrm{H}), 7.28$ (m, 5H), 7.93(d, $J=5.8 \mathrm{~Hz}, 6 \mathrm{H})$. MS (ES) $\mathrm{m} / \mathrm{z} 501.2$ $[\mathrm{M}-\mathrm{H}]^{-}$.

2'-O-[2-(sulfooxy)ethyl]monosodium salt-5-methyluridine (3). Compound $2(5 \mathrm{~g}, 9.53 \mathrm{mmol})$ was dissolved in a mixture of $\mathrm{EtOH}(30 \mathrm{~mL})$ and $\mathrm{AcOH}(30 \mathrm{~mL})$. To this mixture was added palladium hydroxide $(1 \mathrm{~g})$, and it was allowed to shake on a Parr hydrogenation apparatus at $55 \mathrm{psi}$ of $\mathrm{H}_{2}$ overnight. The reaction was monitored by TLC $\left(20 \% \mathrm{MeOH}\right.$ in $\mathrm{CH}_{2-}$ $\mathrm{Cl}_{2}$ ). After the reaction was complete, the solution was filtered through a bed of Celite and concentrated to dryness in vacuo. The crude product $\mathbf{3}$ was used for the next step without further purification.

2'-O-[2-(methylthio)ethyl]-5-methyluridine (4). Compound $3(3.64 \mathrm{~g}, 9.53 \mathrm{mmol}$, amount based on $100 \%$ conversion of compound 1) was dissolved in $70 \mathrm{~mL} \mathrm{DMF}$, and sodium thiomethoxide $(6.68 \mathrm{~g}, 95.3 \mathrm{mmol})$ was added as a solid. The reaction mixture was heated at $80{ }^{\circ} \mathrm{C}$ for $18 \mathrm{~h}$. The reaction was complete after this time as indicated by TLC (10\% $\mathrm{MeOH}$ in $\mathrm{CH}_{2} \mathrm{Cl}_{2}$ ). The reaction mixture was poured into water $(50 \mathrm{~mL})$ and extracted with ethyl acetate $(50 \mathrm{~mL})$. The organic phase was washed with brine $(50 \mathrm{~mL})$, dried over anhydrous $\mathrm{MgSO}_{4}$, filtered, and evaporated to dryness. The residue was purified by silica gel column chromatography and eluted with ethyl acetate to yield $4(1.61 \mathrm{~g}, 56 \%)$. ${ }^{1} \mathrm{H}$ NMR $\left(200 \mathrm{MHz}, \mathrm{CDCl}_{3}\right) \delta 1.92(\mathrm{~s}, 3 \mathrm{H}), 2.15(\mathrm{~s}, 3 \mathrm{H})$, $2.69(\mathrm{~m}, 3 \mathrm{H}), 3.20(\mathrm{~d}, J=4.1 \mathrm{~Hz}, 2 \mathrm{H}), 3.64-3.88(\mathrm{~m}, 2 \mathrm{H})$, $4.05(\mathrm{~s}, 3 \mathrm{H}), 4.21(\mathrm{t}, J=4.42 \mathrm{~Hz}, 1 \mathrm{H}), 4.35(\mathrm{t}, J=4.68 \mathrm{~Hz}$, $1 \mathrm{H}), 4.71(\mathrm{~s}, 2 \mathrm{H}), 5.49(\mathrm{~s}, 2 \mathrm{H}), 5.65(\mathrm{~d}, J=5.48 \mathrm{~Hz}, 1 \mathrm{H})$, $7.45(\mathrm{~s}, 1 \mathrm{H})$; HRMS (FAB) calcd for $\mathrm{C}_{13} \mathrm{H}_{20} \mathrm{~N}_{2} \mathrm{O}_{6} \mathrm{SCs}^{+}$ 465.1515, found 465.1510 .

5'-O-(4,4'-Dimethoxytrityl)-2'-O-[2-(methylthio)ethyl]-5methyluridine (5). Compound 4 (3.16 g, $9.53 \mathrm{mmol})$ was dissolved in anhydrous pyridine $(40 \mathrm{~mL})$, and solid $4,4^{\prime}$ dimethoxytrityl chloride (DMTCl) $(3.23 \mathrm{~g}, 9.53 \mathrm{mmol})$ was added in one portion, and the mixture was stirred overnight at room temperature under inert atmosphere. The reaction was monitored by TLC (40\% EtOAc in $\mathrm{CH}_{2} \mathrm{Cl}_{2}$ ). The reaction mixture was partitioned between ethyl acetate (70 $\mathrm{mL})$ and water $(50 \mathrm{~mL})$. The aqueous layer was extracted with EtOAc $(2 \times 25 \mathrm{~mL}$ each). The combined organic phase was washed with water $(30 \mathrm{~mL})$ and brine $(30 \mathrm{~mL})$ and dried over anhydrous $\mathrm{MgSO}_{4}$. The organic layer was evaporated in vacuo to give a yellow residue. The residue was purified by silica gel column chromatography and eluted with $30 \%$ ethyl acetate in $\mathrm{CH}_{2} \mathrm{Cl}_{2}$ to afford compound $\mathbf{5}$ in 34\% (2.05 g). ${ }^{1} \mathrm{H}$ NMR $\left(200 \mathrm{MHz}, \mathrm{DMSO}-d_{6}\right) \delta 1.40(\mathrm{~s}, 3 \mathrm{H}), 2.06(\mathrm{~s}$, $3 \mathrm{H}), 2.61(\mathrm{t}, J=6.8 \mathrm{~Hz}, 2 \mathrm{H}), 3.23(\mathrm{~m}, 2 \mathrm{H}), 3.63-3.86(\mathrm{~m}$, 2H), $3.73(\mathrm{~s}, 6 \mathrm{H}), 3.95(\mathrm{~m}, 1 \mathrm{H}), 4.04(\mathrm{t}, J=4.6 \mathrm{~Hz}, 1 \mathrm{H})$, $4.22(\mathrm{q}, J=5.6 \mathrm{~Hz}, 1 \mathrm{H}), 5.15(\mathrm{~d}, J=6.4 \mathrm{~Hz}, 1 \mathrm{H}), 5.84(\mathrm{~d}$, $J=4.4 \mathrm{~Hz}, 1 \mathrm{H}), 6.89(\mathrm{~d}, 8.8 \mathrm{~Hz}, 4 \mathrm{H}), 7.23-7.41(\mathrm{~m}, 9 \mathrm{H})$, 7.49 (s, $1 \mathrm{H}), 11.37(\mathrm{~s}, 1 \mathrm{H}) ;{ }^{13} \mathrm{C}$ NMR $\left(50 \mathrm{MHz}, \mathrm{CDCl}_{3}\right) \delta$ $11.78,15.86,34.16,55.23,61.91,69.00,69.31,82.50,83.47$, $86.87,87.68,110.97,113.29,127.14,128.01,128.17,130.11$, 135.28, 135.41, 144.31, 150.15, 158.73, 163.62; MS (ES) $\mathrm{m} / \mathrm{z} 633[\mathrm{M}-\mathrm{H}]^{-}$; HRMS (FAB) calcd for $\mathrm{C}_{34} \mathrm{H}_{39} \mathrm{~N}_{2} \mathrm{O}_{8} \mathrm{~S}$ 634.2416, found 634.2427. Anal. Calcd for $\mathrm{C}_{34} \mathrm{H}_{38} \mathrm{~N}_{2} \mathrm{O}_{8} \mathrm{~S} \cdot$ $\mathrm{H}_{2} \mathrm{O}:$ C, 62.56; H, 6.18; N, 4.29. Found: $\mathrm{C}, 62.87 ; \mathrm{H}, 6.00$; $\mathrm{N}, 4.10$.

$5^{\prime}-O-\left(4,4^{\prime}-\right.$ Dimethoxytrityl $)-2^{\prime}-O-[2-($ methylthio $)$ ethyl-5methyluridine-3'-O-[(2-cyanoethyl) $N, N$-diisopropyl]phosphoramidite (6). Compound 5 (1 g, $1.58 \mathrm{mmol}$ ) was dissolved in anhydrous $\mathrm{CH}_{2} \mathrm{Cl}_{2}(30 \mathrm{~mL})$. To this solution was added $N, N$-diisopropylammonium tetrazolide $(297 \mathrm{mg}$, $1.73 \mathrm{mmol}$ ), followed by 2-cyanoethyl $N, N, N^{\prime} N^{\prime}$-tetraisopropylphosphorodiamidite $(0.6 \mathrm{~mL}, 1.89 \mathrm{mmol})$. The reaction mixture was stirred at room temperature under inert atmosphere for $20 \mathrm{~h}$. The reaction mixture was diluted with ethyl acetate $(50 \mathrm{~mL})$ and washed with saturated sodium bicarbonate $(50 \mathrm{~mL})$ and brine $(50 \mathrm{~mL})$. The organic layer was dried over anhydrous $\mathrm{MgSO}_{4}$, filtered, and concentrated to yield yellow foam. The product was purified by silica gel chromatography (25\% ethyl acetate in $\mathrm{CH}_{2} \mathrm{Cl}_{2}$ ). The appropriate fractions were collected and dried in vacuo. The residue was dissolved in a minimal amount of anhydrous $\mathrm{CH}_{2} \mathrm{Cl}_{2}(5 \mathrm{~mL})$ and slowly added into vigorously stirring hexane $(300 \mathrm{~mL})$. The precipitate obtained was collected by decanting the solvent to yield $6(1.10 \mathrm{~g}, 83 \%) .{ }^{31} \mathrm{P}$ NMR $\left(162 \mathrm{MHz}, \mathrm{CDCl}_{3}\right) \delta 151.17,151.32$; HRMS (FAB) calcd for $\mathrm{C}_{43} \mathrm{H}_{56} \mathrm{~N}_{4} \mathrm{O}_{9} \mathrm{PS}$ 835.35057, found 835.35051.

5'-O-(4,4'-Dimethoxytrityl)-2'-O-[2-(methylthio)ethyl]-3'O-succinyl-5-methyluridine (7). Compound 5 (0.3 g, 0.47 $\mathrm{mmol})$ was mixed with succinic anhydride $(0.07 \mathrm{~g}, 0.71$ mmol) and DMAP (0.03 g, $0.24 \mathrm{mmol})$ and dried over $\mathrm{P}_{2} \mathrm{O}_{5}$ 
in vacuo overnight. The mixture was dissolved in $\mathrm{ClCH}_{2}-$ $\mathrm{CH}_{2} \mathrm{Cl}(1 \mathrm{~mL})$, anhydrous triethylamine $(0.33 \mathrm{~mL}, 2.36$ mmol) was added, and the mixture was stirred at room temperature for $18 \mathrm{~h}$. The progress of the reaction was monitored by TLC $\left(5 \% \mathrm{MeOH}\right.$ in $\left.\mathrm{CH}_{2} \mathrm{Cl}_{2}\right)$. The reaction mixture was diluted with $\mathrm{CH}_{2} \mathrm{Cl}_{2}(30 \mathrm{~mL})$ and washed with ice cold aqueous citric acid $(30 \mathrm{~mL})$ and brine $(30 \mathrm{~mL})$. The organic phase was dried over anhydrous $\mathrm{Na}_{2} \mathrm{SO}_{4}$ and evaporated to dryness in vacuo. The residue was purified by column chromatography and eluted with $10 \% \mathrm{MeOH}$ in $\mathrm{CH}_{2} \mathrm{Cl}_{2}$ containing $1 \%$ triethylamine to yield $7(0.20 \mathrm{~g}, 51 \%)$. ${ }^{1} \mathrm{H}$ NMR $\left(400 \mathrm{MHz}, \mathrm{CDCl}_{3}\right) \delta 1.36(\mathrm{~s}, 3 \mathrm{H}), 2.1(\mathrm{~s}, 3 \mathrm{H})$, $2.57-2.69(\mathrm{~m}, 6 \mathrm{H}), 3.39(\mathrm{~d}, J=2.14 \mathrm{~Hz}, 1 \mathrm{H}), 3.51-3.59$ $(\mathrm{m}, 3 \mathrm{H}), 3.77(\mathrm{~m}, 2 \mathrm{H}), 3.78(\mathrm{~s}, 6 \mathrm{H}), 4.27(\mathrm{brs}, 1 \mathrm{H}), 4.31(\mathrm{t}$, $J=5.34 \mathrm{~Hz}, 1 \mathrm{H}), 5.35(\mathrm{t}, J=4.7 \mathrm{~Hz}, 1 \mathrm{H}), 6.03(\mathrm{~d}, J=$ $5.34 \mathrm{~Hz}, 1 \mathrm{H}), 6.83(\mathrm{~d}, J=8.97 \mathrm{~Hz}, 4 \mathrm{H}), 7.23-7.37(\mathrm{~m}$, 9H), 7.57 (s, 1H); ${ }^{13} \mathrm{C}$ NMR (100 MHz, $\left.\mathrm{CDCl}_{3}\right) \delta 11.71$, $30.07,30.72,33.51,55.28,62.52,63.37,70.59,70.65,80.41$, $81.46,86.97,87.21,111.32,113.37,127.24,128.06,128.17$, $130.11,135.06,135.15,135.34,144.13,150.36,158.80$, 163.63, 172.61, 176.36; HRMS (FAB) calcd for $\mathrm{C}_{38} \mathrm{H}_{42} \mathrm{~N}_{2} \mathrm{O}_{11} \mathrm{~S}$ 734.2509, found 734.2496.

5'-O-(4,4'-Dimethoxytrityl)-2'-O-[2-(methylthio)ethyl]-5methyluridine-3'-O-succinyl CPG (8). Compound 7 was loaded on to LCAA-CPG, following a reported procedure $(13,14)$, and a final loading of $56 \mu \mathrm{mol} / \mathrm{g}$ was obtained.

Oligonucleotide Synthesis, Purification, and Characterization. A $0.1 \mathrm{M}$ solution of the amidite 6 in anhydrous acetonitrile was used for the synthesis of modified oligonucleotides. The oligonucleotides were synthesized on functionalized controlled pore glass (CPG) on an automated solidphase DNA synthesizer. CPG 8 functionalized with $2{ }^{\prime}-O$ MTE modified nucleoside was used for the synthesis of oligonucleotide 18. For incorporation of $\mathbf{6}$, phosphoramidite solution was delivered in two portions, each followed by a 5 min coupling wait time. Oxidation of the internucleotide phosphite to phosphate was carried out using a $10 \%$ tert$\mathrm{BuOOH}$ in acetonitrile (15) with 10 min waiting time for oxidation. All other steps in the protocol supplied by the manufacturer were used without modification. The coupling efficiencies were more than $98 \%$. After completion of the synthesis, the CPG was suspended in aqueous ammonia (28$30 \mathrm{wt} \%$ ) at room temperature for $2 \mathrm{~h}$ to cleave the oligonucleotide from the CPG. The CPG was filtered; the filtrate was then heated at $55^{\circ} \mathrm{C}$ for $6 \mathrm{~h}$ to effect the complete removal of the base-labile protecting groups. Crude oligonucleotides were purified by High Performance Liquid Chromatography (HPLC, C-4, Waters, $7.8 \times 300 \mathrm{~mm}, \mathrm{~A}=$ $50 \mathrm{mM}$ triethylammonium acetate (TEAAc), $\mathrm{pH} \mathrm{7,} \mathrm{B} \mathrm{=}$ acetonitrile, $5-60 \% \mathrm{~B}$ in $55 \mathrm{~min}$, Flow $2.5 \mathrm{~mL} \mathrm{~min}^{-1}, \lambda=$ $260 \mathrm{~nm}$ ). The fractions containing full-length oligonucleotides were pooled together, and the $\mathrm{pH}$ of the solution was adjusted to 4.2 with acetic aicd and kept at room temperature for $24 \mathrm{~h}$ to complete detritylation. The detritylated oligonucleotides were desalted by HPLC on a Waters C- 4 column to yield the 2 -modified oligonucleotides in $30-35 \%$ isolated yield. A list of all oligonucleotides used for this study are given in Table 1. Oligonucleotides were characterized by ESMS (Table 2), and purity was assessed by HPLC (Table 2) and Capillary Gel Electrophoresis (CGE).

Nuclease Stability Determination. Oligonucleotides, at a final concentration of $2 \mu \mathrm{M}$, were incubated with snake

\begin{tabular}{|c|c|c|}
\hline \multicolumn{3}{|l|}{ oligo } \\
\hline no. & sequence & backbone $^{b}$ \\
\hline 9 & $5^{\prime} \mathrm{d}(\mathrm{GCG}$ TTT TTT TTT TGC G) 3' & $\mathrm{P}=\mathrm{O}$ \\
\hline 10 & $5^{\prime} \mathrm{d}\left(\mathrm{GCG} \mathrm{T}^{*} \mathrm{~T} * \mathrm{~T} * \mathrm{~T}^{*} \mathrm{~T} * \mathrm{~T}^{*} \mathrm{~T} * \mathrm{~T} * \mathrm{~T}^{*} \mathrm{~T} * \mathrm{GC} \mathrm{G}\right) 3^{\prime}$ & $\mathrm{P}=\mathrm{O}$ \\
\hline 11 & $5^{\prime} \mathrm{d}\left(\mathrm{GCG} \mathrm{T}^{\S} \mathrm{T}^{\S} \mathrm{T}^{\S} \mathrm{T}^{\S} \mathrm{T}^{\S} \mathrm{T}^{\S} \mathrm{T}^{\S} \mathrm{T}^{\S} \mathrm{T}^{\S} \mathrm{T}^{\S} \mathrm{GC} \mathrm{G}\right) 3^{\prime}$ & $\mathrm{P}=\mathrm{O}$ \\
\hline 12 & $5^{\prime} \mathrm{d}$ (CTC GTA CTT TTC CGG TCC) $3^{\prime}$ & $\mathrm{P}=\mathrm{O}$ \\
\hline 13 & $5^{\prime} \mathrm{d}\left(\mathrm{CTC}\right.$ GTA CT $* \mathrm{~T}^{*} \mathrm{~T}^{*} \mathrm{~T}^{*} \mathrm{C}$ CGG TCC $) 3^{\prime}$ & $\mathrm{P}=\mathrm{O}$ \\
\hline 14 & $5^{\prime} \mathrm{d}\left(\mathrm{CTC}\right.$ GTA C $\mathrm{CT}^{\S} \mathrm{T}^{\S} \mathrm{T}^{\S} \mathrm{T}^{\S} \mathrm{C}$ CGG TCC $) 3^{\prime}$ & $\mathrm{P}=\mathrm{O}$ \\
\hline 15 & $5^{\prime} \mathrm{d}(\mathrm{TCC}$ AGG TGT CCG CAT C) 3' & $\mathrm{P}=\mathrm{O}$ \\
\hline 16 & $5^{\prime} \mathrm{d}\left(\mathrm{T}^{*} \mathrm{CC}\right.$ AGG T*GT* CCG CAT* C) $3^{\prime}$ & $\mathrm{P}=\mathrm{O}$ \\
\hline 17 & $5^{\prime} \mathrm{d}\left(\mathrm{T}^{\S} \mathrm{CC} \mathrm{AGG} \mathrm{T}^{\S} \mathrm{GT}^{\S} \mathrm{CCG} \mathrm{CAT}^{\S} \mathrm{C}\right) 3^{\prime}$ & $\mathrm{P}=\mathrm{O}$ \\
\hline 18 & $5^{\prime}$ TTT TTT TTT TTT TTT T*T*T* T* & $\mathrm{P}=\mathrm{O}$ \\
\hline 19 & $5^{\prime}$ d(GCG TTT TTT TTT TGC G) 3' & $\mathrm{P}=\mathrm{S}$ \\
\hline 20 & $5^{\prime}$ d(GCGTAT*ACGC) 3' & $\mathrm{P}=\mathrm{O}$ \\
\hline
\end{tabular}

${ }^{a} \mathrm{~T}^{*}=2^{\prime}-O$-MTE-5 -methyluridine, $\mathrm{T}^{\S}=2^{\prime}$-O-MOE-5-methyluridine. ${ }^{b} \mathrm{P}=\mathrm{O}$ refers to phosphodiesters, and $\mathrm{P}=\mathrm{S}$ refers to phosphorothioates.

Table 2: HPLC and Mass Spectral Analysis of 2'-O-MTE Oligonuleotides Used for the Study

\begin{tabular}{cccc}
\hline \multirow{2}{*}{$\begin{array}{c}\text { oligo } \\
\text { no. }\end{array}$} & \multicolumn{2}{c}{ mass } & $\begin{array}{c}\text { HPLC retention } \\
\text { time, min. }{ }^{a}\end{array}$ \\
\cline { 2 - 3 } & calcd. & found & 38.08 \\
10 & 5778.34 & 5776.00 & 31.43 \\
13 & 5754.85 & 5752.8 & 26.89 \\
16 & 5194.38 & 5193.60 & 33.51 \\
18 & 6080.09 & 6078.40 & 25.39 \\
20 & 3119.51 & 3119.80 & \\
\hline
\end{tabular}

${ }^{a}$ Waters, C-4, $3.9 \times 300 \mathrm{~mm}, \mathrm{~A}=50 \mathrm{mM}$ triethylammonium acetate, $\mathrm{pH} 7, \mathrm{~B}=$ acetonitrile, $5-60 \% \mathrm{~B}$ in $55 \mathrm{~min}$, Flow $1.5 \mathrm{~mL}$ $\min ^{-1}, \lambda=260 \mathrm{~nm}$.

venom phosphodiesterase $(0.005 \mathrm{U} / \mathrm{mL})$ in $50 \mathrm{mM}$ Tris- $\mathrm{HCl}$, $\mathrm{pH} 7.5,8 \mathrm{mM} \mathrm{MgCl}{ }_{2}$ at $37^{\circ} \mathrm{C}$. The total reaction volume was $100 \mu \mathrm{L}$. At each time point, $10 \mu \mathrm{L}$ aliquots of each reaction mixture were placed in a $500 \mu \mathrm{L}$ microfuge tube and put in a boiling water bath for two minutes. The sample was then cooled on ice and spun in a Microfuge to bring the entire volume to the bottom of the tube. The reaction mixture was desalted on a Millipore $0.025 \mu \mathrm{m}$ filter disk (Bedford, MA) that was floating in water in a $60 \mathrm{~mm}$ Petrie dish. After 30-60 min on the membrane, the sample was diluted with $200 \mu \mathrm{L}$ distilled $\mathrm{H}_{2} \mathrm{O}$ and analyzed by gel-filled capillary electrophoresis. The oligonucleotide and metabolites were separated and analyzed using the Beckman P/ACE MDQ capillary electrophoresis instrument using a $100 \mu \mathrm{m}$ ID 30 $\mathrm{cm}$ coated capillary (Beckman No. 477477) with eCAP ssDNA 100-R gel (Beckman No. 477621) and Tris-Borate Urea buffer (Beckman No. 338481). The samples were injected electrokinetically using a field strength of between 5 and $10 \mathrm{kV}$ for a duration of between 5 and $10 \mathrm{~s}$. Separation was achieved at $40{ }^{\circ} \mathrm{C}$ with an applied voltage of $15 \mathrm{kV}$. The percentage of full-length oligonucleotide was calculated by integration using Caesar v. 6 software (Senetec Software, $\mathrm{NJ}$ ), followed by correction for differences in extinction coefficient for oligonucleotides of different length.

Binding of oligonucleotides to human serum albumin. The $5^{\prime}$ end of each oligonucleotide was end labeled with ${ }^{32} \mathrm{P}$ using $\mathrm{T} 4$ polynucleotide kinase using standard procedures. Unincorporated label was removed using a G25 column and was confirmed by polyacrylamide gel electrophoresis. A fixed concentration of labeled oligonucleotide $(50 \mathrm{nM})$ was incubated with increasing concentrations of albumin (fatty acid free human serum albumin, Sigma Chemical, St. Loius, 
MO) and incubated at $25{ }^{\circ} \mathrm{C}$ for $1 \mathrm{~h}$ in phosphate-buffered saline buffer containing $0.1 \mathrm{mM}$ EDTA and $0.005 \%$ Tween 80. After incubation, the samples were loaded onto low binding, regenerated cellulose filter membranes with a molecular weight cutoff of 30,000 (Millipore). The samples were spun gently in a microfuge (NYCentrifuge 5415C; Eppendorf, Westbury, NY) at $3000 \mathrm{rpm}(735 \mathrm{~g})$ for 3-6 min, collecting $\sim 20 \%$ of the loaded volume in the filtrate.

Aliquots from the filtrate and the initial (unfiltered) solutions were measured using scitillation counter (model LS6000IC, Beckman, Fullerton, CA). The counts obtained in the filtrate aliquots represent the free (unbound) oligonucleotide and appropriate calculations are performed to obtain the concentration of free oligonucleotide. Further calculations yield the concentration of oligonucleotide bound to protein.

The fraction of oligonucleotide bound was plotted versus total albumin concentration. The equilibrium constant, $K_{\mathrm{d}}$, was determined by fitting the data of fraction of oligonucleotide bound to protein concentration. Constants were determined from nonlinear regression analysis of a fraction of ODN bound ( $\left.f_{\text {bound }}\right)$ as a function of free albumin monomer concentration $\left([\mathrm{A}]_{\text {free }}\right)$. Concentration of albumin monomers in solution was calculated using $K_{\mathrm{d}}=150 \mu \mathrm{M}$ for monomerdimer equilibrium $(16,17)$.

Crystallization and Structure Determination. Optimal crystallization conditions for the modified decamer were screened by the sparse matrix crystallization technique, using the Hampton Research (Laguna Niguel, CA) nucleic acid mini screen. Crystals for data collection were grown by the hanging-drop vapor-diffusion method. Equal volumes of a $2 \mathrm{mM}$ oligonucleotide solution in water and a buffer solution, containing $40 \mathrm{mM}$ sodium cacodylate $(\mathrm{pH} 7.0), 80 \mathrm{mM}$ potassium chloride, $12 \mathrm{mM}$ spermine tetrahydrochloride and $10 \%$ (v/v) 2-methyl-2,4-pentanediol (MPD), were mixed and equilibrated against $1 \mathrm{~mL} 35 \%$ (v/v) MPD. Diffraction data to a maximum resolution of $1.2 \AA$ were collected on a single flash-frozen $(100 \mathrm{~K})$ crystal at a wavelength of $1 \AA$ on the 5-ID beamline at the Advanced Photon Source (DuPontNorthwestern-Dow Collaborative Access Team, Argonne, IL), using a MARCCD detector. Data were integrated and merged in the DENZO/SCALEPACK suite (18). The structure was solved by the molecular replacement method using the program AMORE (19). Initial rounds of crystallographic refinement were performed with the program CNS (20). The program SHELXL-97 (21) was used for anisotropic temperature factor refinement and calculation of hydrogen atom positions. All DNA atoms and selected water molecules were refined anisotropically, and a summary of crystal data and refinement parameters is listed in Table 5. An example of the final $\left(2 F_{\mathrm{o}}-F_{\mathrm{c}}\right)$ Fourier sum electron density around the 2 - $O$-MTE-modified residue $\mathrm{T}^{*} 16$ in the decamer is depicted in Figure 4.

Coordinates. Structure factors and final coordinates have been deposited in the Brookhaven Protein Databank (entry code 1MLX).

\section{RESULTS AND DISCUSSION}

We recently reported a novel and efficient scheme to synthesize the 2'-O-MTE modified 5-methyluridine nucleoside $\mathbf{1}$ and the corresponding amidite $\mathbf{2}$ (22) involving
Table 3: Effect of 2'-O-MTE and 2'-O-MOE Modification on Duplex Stability against Complementary RNA

\begin{tabular}{cccc}
\hline $\begin{array}{c}\text { oligo } \\
\text { no. }\end{array}$ & $\begin{array}{c}T_{\mathrm{m}} \\
\left({ }^{\circ} \mathrm{C}\right)\end{array}$ & $\begin{array}{c}\Delta T_{\mathrm{m}} \\
\left({ }^{\circ} \mathrm{C}\right)\end{array}$ & $\begin{array}{c}\Delta T_{\mathrm{m}}\left({ }^{\circ} \mathrm{C}\right) / \\
\text { modification }\end{array}$ \\
\hline 9 & 48.3 & & \\
10 & 60.1 & 11.8 & 1.18 \\
11 & 60.4 & 12.1 & 1.2 \\
12 & 61.8 & & \\
13 & 66.4 & 4.64 & 1.16 \\
14 & 65.3 & 3.6 & 0.9 \\
15 & 62.3 & & \\
16 & 66.58 & 4.28 & 1.07 \\
17 & 65.9 & 3.6 & 0.9 \\
\hline
\end{tabular}

Table 4: Effect of 2'-Modifcation on Human SerumAlbumin Binding Constant of the Oligonucleotide

\begin{tabular}{|c|c|c|c|}
\hline \multirow{2}{*}{$\begin{array}{l}\text { oligo } \\
\text { no. }\end{array}$} & \multicolumn{2}{|r|}{ chemistry } & \multirow[b]{2}{*}{$K_{\mathrm{d}}(\mu \mathrm{M})$} \\
\hline & backbone & 2'-modification & \\
\hline 9 & full $\mathrm{P}=\mathrm{O}$ & $\begin{array}{l}2^{\prime} \text {-deoxy- } \\
\text { thymidine }\end{array}$ & no binding \\
\hline 10 & full $\mathrm{P}=\mathrm{O}$ & 2'-O-MTE-5-methyluridine & 188 \\
\hline 11 & full $\mathrm{P}=\mathrm{O}$ & $2^{\prime}-O$-MOE-5-methyluridine & no binding \\
\hline 19 & full $\mathrm{P}=\mathrm{S}$ & $2^{\prime}$-deoxy-thymidine & 30 \\
\hline
\end{tabular}
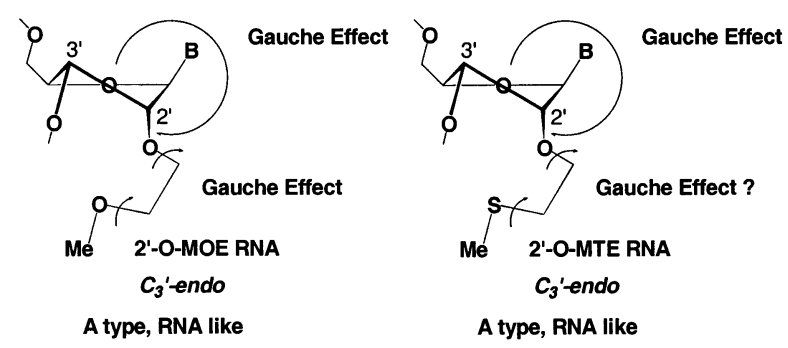

FIGURE 2: Conformational preorganization of 2'-O-MOE RNA due to multiple gauche effects and possibility of similar effects in $2^{\prime}$ $O$-MTE RNA

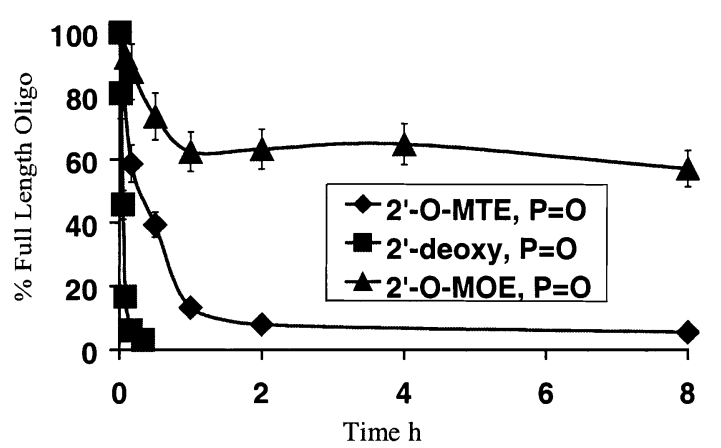

FIGURE 3: Relative nuclease resistance of the $2^{\prime}$ - $O$-MTE oligonucleotide vs the $2^{\prime}-O$-MOE and $2^{\prime}$-deoxy oligonucleotides. T* represents $2^{\prime}$-modified ${ }^{5 \mathrm{Me}} \mathrm{U}$. The modifications were placed at the $3^{\prime}$ end of the sequence 18 TTT TTT TTT TTT TTT T*T*T* T* and digested with snake venom phosphodiesterase.

alkylation of the 2'-O-position. Alkylation of the 2'-O position of a nucleoside using a five- or six-membered cyclic sulfate followed by nucleophilic displacement creates a modified nucleoside in only two or three synthetic steps (Scheme 1). We used this synthetic strategy to synthesize $2^{\prime}-O-[($ methylthio)ethyl $]$ nucleoside (Scheme 1). Treatment of the $N^{3}$-[(phenylmethoxy)methyl]-5-methyluridine (1) with $\mathrm{NaH}$ in DMF at $-45^{\circ} \mathrm{C}$ followed by addition of the cyclic sulfate (1,3,2-dioxathiolane 2,2-dioxide) afforded the compound $\mathbf{2}$ in $63 \%$ yield (Scheme 1). The selectivity for $2^{\prime}$ over $3^{\prime}$ alkylation was about 3:1. The attempt to nucleophilic 


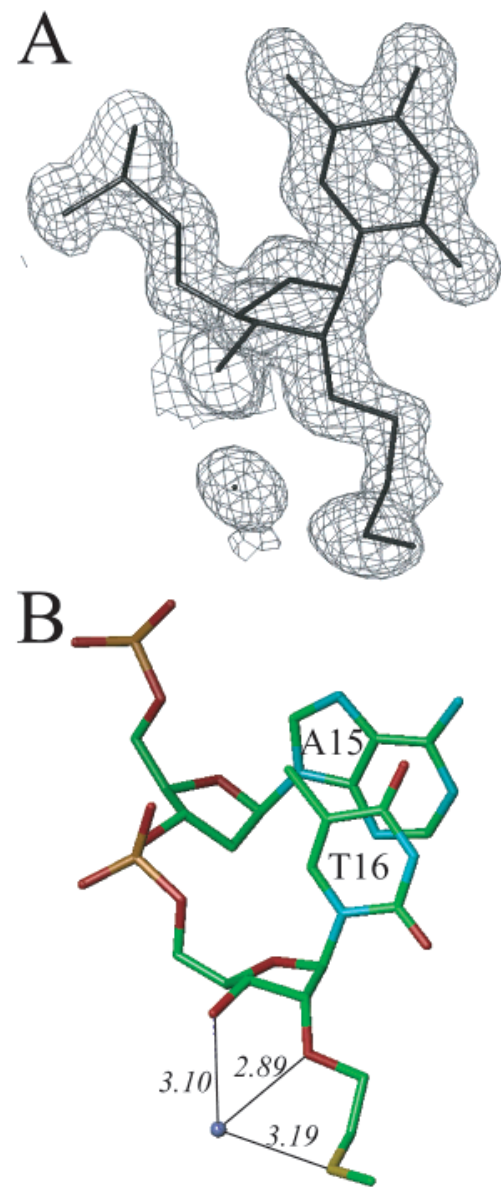

FiguRE 4: (A) $\left(2 F_{\mathrm{o}}-F_{\mathrm{c}}\right)$ Fourier sum electron density ( $1 \sigma$ level $)$ surrounding the $2^{\prime}-O$-MTE-modified residue $\mathrm{T}^{*} 16$ in the final model of the duplex. (B) Conformation and hydration of the $2^{\prime}-O$-MTE substituent of residue $\mathrm{T} * 16$. Atoms are colored green, red, cyan, orange, and yellow for carbon, oxygen, nitrogen, phosphorus, and sulfur, respectively, residues are labeled, a bound water molecule is shown as a blue sphere, and hydrogen bonds are thin solid lines with distances shown in $\AA$.

displacement of sulfate group of nucleoside $\mathbf{2}$ with sodium methyl mercaptide was successful. However, deprotection of $N^{3}$-[(phenylmethoxy)methyl] (BOM) under catalylic hydrogentaion in the presence of palladium hydroxide failed to get the expected product. This may be attributed to poisoning of the palladium hydroxide catalyst by the sulfide side chain. Hence, an alternate route was used, where the BOM group of the sulfate derivative $\mathbf{2}$ was removed first via catalytic hydrogenation over a palladium hydroxide catalyst to yield $\mathbf{3}$, which was subjected to nucleophilic displacement with $\mathrm{NaSCH}_{3}$ to give compound 4. The crude compound 4 was selectively protected at $5^{\prime}$-hydroxyl by reacting with $4,4^{\prime}$-dimethoxytrityl chloride (DMTCl) and a catalytic amount of DMAP in anhydrous pyridine to yield 5. Phosphitylation of $\mathbf{5}$ at the $3^{\prime}$-position afforded the phosphoramidite building block 6 in $63 \%$ yield. The nucleoside 5 was converted into $3^{\prime}-O$ - succinyl derivative 7 and loaded onto the aminoalkyl controlled pore glass (CPG) to yield the functionalized CPG $8(56 \mu \mathrm{mol} / \mathrm{g})$.

The 2 - $O$-MTE modified oligonucleotides used in this study were synthesized on a solid-phase DNA synthesizer using phosphoramidite 6. A $0.1 \mathrm{M}$ solution of phosphoramidite in anhydrous acetonitrile was used for the synthesis. The overall coupling efficiency of modified phosphoramidite
Scheme $1^{a}$
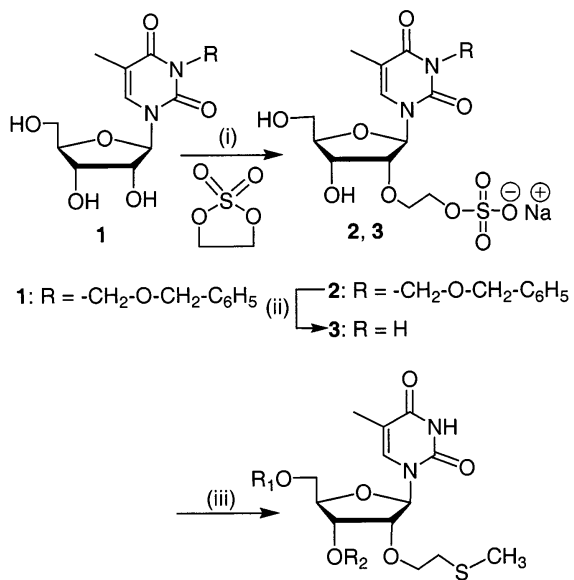

$4,5,6,7,8$

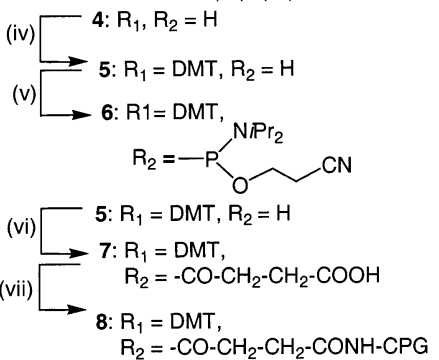

${ }^{a}$ (i) $\mathrm{DMF}, \mathrm{NaH},-45^{\circ} \mathrm{C}$ to rt (ii) $\mathrm{Pd}(\mathrm{OH})_{2}, \mathrm{EtOH}, \mathrm{CH}_{3} \mathrm{COOH}, \mathrm{H}_{2}$ (iii) DMF, $\mathrm{MeS}^{-} \mathrm{Na}^{+}, 80^{\circ} \mathrm{C}$ (iv) DMTCl, Py, DMAP, rt (v) 2-cyanoethyl $N, N, N^{\prime}, N^{\prime}$-tetraisopropylphosphorodiamidite, $\mathrm{CH}_{2} \mathrm{Cl}_{2}, N, N$ diisopropylaminetetrazolide, rt (vi) Succinic anhydride, DMAP, TEA, 1,2-dichloroethane (vii) 2-(1-H-benzotriazole-1-yl)-1,1,3,3-tetramethyluroniumetrafluoroborate (TBTU), $N$-methylmorpholine, aminoalkyl controlled pore glass (CPG), DMF.

was more than $98 \%$. Since thioethers are sensitive to $\mathrm{I}_{2} / \mathrm{H}_{2} \mathrm{O}$, the standard oxidizing agent for oxidizing trivalent phosphorus, a solution of $10 \%$ tert $-\mathrm{BuOOH}$ in acetonitrile was used as the oxidizing agent during the solid-phase synthesis (15). This oxidizing agent did not cause any modification to the sulfur of the $2^{\prime}-O$-MTE substituent, as indicated by mass spectrometry and crystallographic results. All oligonucleotides were characterized by ESMS (Table 2), and purity was assessed by HPLC and Capillary Gel Electophoresis.

The binding affinity of 2'-O-MTE modified oligonucleotides to the target RNA was determined by obtaining the Tm values from the temperature-dependent UV absorbance profile of the duplexes. The binding affinity of the $2^{\prime}-O$ MTE oligonucleotides was similar to that of the $2^{\prime}-O-\mathrm{MOE}$ oligomers (Table 3). The observed difference of $1.2{ }^{\circ} \mathrm{C} /$ modification for $2^{\prime}$-O-MTE translates to a nearly $2{ }^{\circ} \mathrm{C}$ increase/modification when compared to the $2^{\prime}-\mathrm{H} / \mathrm{P}=\mathrm{S}$ compounds (23). It was surprising that substitution of $2^{\prime}-O$ MTE for $2^{\prime}-O-M O E$ did not have an adverse effect on binding affinity, considering that the sulfur atom is larger than oxygen and thus could cause steric hindrance in the RNA-antisense oligomer duplex formed. Second, the sulfur atom should cause a weaker gauche effect than the oxygen atom (24). Preorganization due to the gauche effect has been used to explain the high binding affinity of the $2^{\prime}-O$ methoxyethyl group (25) (Figure 2). Perhaps the hydrophobicity of the sulfur causes water expulsion from the minor groove, resulting in the observed stabilization in the case of the $2^{\prime}-O$-MTE modified oligonucleotides. 


\begin{tabular}{lc}
\hline Table 5: Selected Crystal Data and Refinement Parameters for the \\
Self-Complementary Modified Decamer Duplex \\
[d(GCGTAT*ACGC) $]_{2}\left(T^{*}=2^{\prime}\right.$-O-MTE-5-Methyluridine) \\
\hline crystal system & orthorhombic \\
space group & $P 2_{1} 2_{1} 2_{1}$ \\
cell constants $(\AA)$ & $a=24.73$, \\
& $b=44.47$, \\
& $c=46.23$ \\
max. resolution $(\AA)$ & 1.20 \\
unique reflections $(15-1.2 \AA)$ & 14,054 \\
completeness $(\%)$ & 96.7 \\
$R$-factor $(\%)$ & 14.1 \\
water molecules & 149 \\
rms bond lengths $(\AA)$ & 0.029 \\
rms angles $(1 . . .3$ dist., $\AA)$ & 0.034 \\
\hline
\end{tabular}

Binding of the 2'-O-MTE modified oligonucleotide $\mathbf{1 0}$ (Table 1) to human serum albumin was measured by ultrafiltration techniques (12). The measured value of $K_{\mathrm{d}}$ shows the affinity of the oliognucleotides to human serum albumin. An oligonuleotide with lower $K_{\mathrm{d}}$ value would bind strongly to the protein than the one with the higher value of $K_{\mathrm{d}}$. We also evaluated human serum albumin binding of 2'$O$-MOE and 2'-deoxy phosphodiester oligonucleotides with the same length and sequence (Table 4). In these experiments 2 '-O-MTE oligomer with a phosphodiester backbone exhibited moderate protein binding while the $2^{\prime}-O-\mathrm{MOE} / \mathrm{P}=\mathrm{O}$ showed no binding (Table 4). The $2^{\prime}$ - $O$-MTE oligomer exhibited weaker binding than 2'-deoxyphosphorothioate oligonucleotides. Differences in plasma protein binding appear to explain the differences in pharmacokinetic behavior of antisense oligonucleotides (12). The moderate binding property of 2'-O-MTE is expected to improve the pharmacokinetic properties of antisense drugs having this modification relative to both $2^{\prime}-O-\mathrm{MOE} / \mathrm{P}=\mathrm{O}$ and phosphorothioate oligonucleotides.

To evaluate the stability of the 2'-O-MTE modified oligonucleotides to nucleases, oligonucleotide $\mathbf{1 8}$ was digested with snake venom phosphodiesterase (SVPD) (26). The modifications in $\mathbf{1 8}$ were placed at the $3^{\prime}$-end and all internucleosidic linkages were phosphodiesters. For comparison, 2'-deoxy analogues and oligonucleotides with the $2^{\prime}-O$-MOE modification in the same positions and sequence were also subjected to SVPD digestion under the same conditions. The products of digestion at different time intervals were analyzed by capillary gel electrophoresis (CGE) and quantified. Figure 3 shows the comparative nuclease resistance of these modified oligonucleotides. The 2 - $O$-MTE oligonucleotide degraded much more rapidly than the 2'-O-MOE modified oligonucleotide, although stability of the $2^{\prime}$-O-MTE oligomer was greater than that of the $2^{\prime}$ deoxy oligonucleotide.

To rationalize the observed differences in protein binding property and stability to nucleases between $2^{\prime}-O$-MTE and $2^{\prime}$ - $O$-MOE oligonucleotides, we undertook crystallographic studies. The decamer $\mathbf{2 0}$ was synthesized, and its crystal structure was determined. The crystal structure of a duplex with identical sequence and with $2^{\prime}-O-\mathrm{MOE}$ in the same positions had previously been reported (27).

The 2'-O-MTE modified decamer duplex exhibits a standard A-type geometry with all 2'-deoxyriboses and the ribose moieties from the two modified residues adopting typical C3'-endo puckers (Table 5). The 2'-O-MTE substitu-
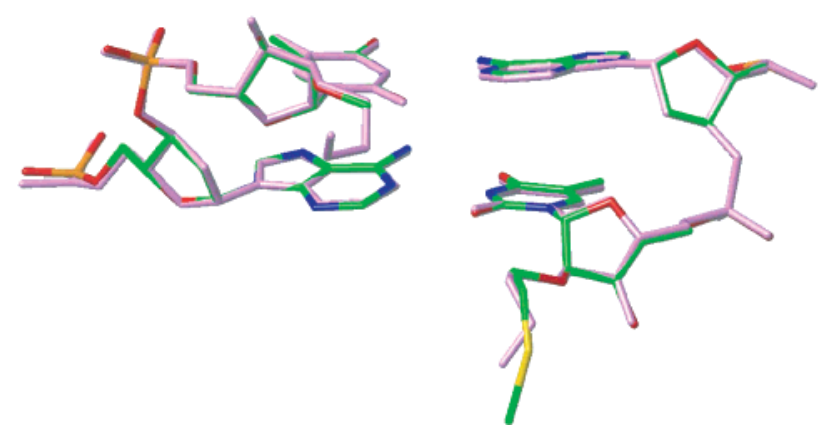

FiguRE 5: Superposition of the A5pT6 $6_{2^{\prime}-O-\mathrm{MTE}}: \mathrm{A} 15 \mathrm{pT} 16_{2^{\prime}-O-\mathrm{MTE}}$ and A5pT6 $2^{\prime}-O-\mathrm{MOE}: \mathrm{A} 15 \mathrm{pT} 16_{2^{\prime}-O-\mathrm{MOE}}$ (purple bonds) base pair steps in the $\left[\mathrm{d}(\right.$ GCGTA $)-\mathrm{T}_{2^{\prime}-O-\mathrm{MTE}}-\mathrm{d}(\text { ACGC) }]_{2}$ and $[\mathrm{d}($ GCGTA $)-$ $\left.\mathrm{T}_{2^{\prime}-O-\mathrm{MOE}}-\mathrm{d}(\mathrm{ACGC})\right]_{2}$ duplexes (27), containing single $2^{\prime}$ - $O$-MTE and $2^{\prime}-O$-MOE thymidines, respectively. The view is into the minor groove and the $2^{\prime}-O$-MTE moieties of $\mathrm{T}^{*} 6$ and $\mathrm{T}^{*} 16$ can be recognized at the upper left (only $\mathrm{O}^{\prime}$ and $\mathrm{CA}^{\prime}$ were visible in the maps) and the lower right, respectively. Atoms of the $2^{\prime}-O$-MTEmodified base pair step are colored green, red, blue, orange, and yellow for carbon, oxygen, nitrogen, phosphorus, and sulfur, respectively.

ent of residue $T^{*} 16$ was well defined in electron density maps (Figure 4). Its geometry was very similar to that observed for a $2^{\prime}-O$-MOE substituent in the crystal structure of the decamer duplex with two incorporated 2'-O-MOE-modified5 -methyluridines (27). In both cases the conformation around the $\mathrm{C}-\mathrm{C}$ bond of the central ethyl linker falls into a $s c^{-}$ range. The torsion angles $\mathrm{O}^{\prime}-\mathrm{CA}^{\prime}-\mathrm{CB}^{\prime}-\mathrm{SC}^{\prime}$ and $\mathrm{O}^{\prime}-\mathrm{CA}^{\prime}-$ $\mathrm{CB}^{\prime}-\mathrm{OC}^{\prime}$ are $-72^{\circ}$ and $-49^{\circ}$ for the MTE and MOE substituents, respectively (substituent atoms are numbered alphabetically). A superposition of the modified base pair steps in the MTE- and MOE-decamer duplexes is depicted in Figure 5.

As previously observed in crystal structures of nucleic acid duplexes bearing 2'-O-MOE modifications $(25,27)$, the 2'$O$-MTE substituent of residue $\mathrm{T}^{*} 16$ provides a binding site for a water molecule. This water forms hydrogen bonds to the $3^{\prime}$ - and the $2^{\prime}$-oxygen atoms as well as to the sulfur atom of the MTE substituent (Figure 4). Unlike in the structure of the $2^{\prime}-O$-MOE modified decamer duplex (27), the MTEsubstituent of the second modified residue $\left(\mathrm{T}^{*} 6\right)$ is disordered, and only the $\mathrm{O}^{\prime}$ and $\mathrm{CA}^{\prime}$ atoms are visible in electron density maps (Figure 5). Because the structure was refined to $1.20 \AA$, the fact that this substituent is invisible cannot be attributed to a lack of resolution. Rather, the T*6 $2^{\prime}-O$-MTE substituent appears to exhibit a lower degree of conformational preorganization compared with the $2^{\prime}-O$-MOE substituent. The hydration motif found for 2'-O-MOE-modified residues and the $2^{\prime}-O$-MTE-modified residue $\mathrm{T}^{*} 16$ probably stabilizes their synclinal conformations. Moreover, the excellent nuclease resistance provided by the $2^{\prime}-O-\mathrm{MOE}$ modification may partly be due to the limited conformational flexibility of the substituent as well as the formation of a water network that spans substituent, sugar and phosphate group (25). The higher flexibility and subsequent lack of a stable water structure observed for one of the two $2^{\prime}-O$-MTE substituents in our crystal structure may hint at possible origins of the more limited resistance to exonuclease degradation seen for the 2'-O-MTE relative to the 2'-O-MOE modification. An alternate explanation for the limited nuclease resistance of the 2'-O-MTE relative to the 2'-O-MOE may be due to differential binding of $\mathrm{Mg}^{2+}$ ions. Stronger 
binding of $\mathrm{Mg}^{2+}$ by the $2^{\prime}-O-\mathrm{MOE}$ side chain, and thus a lowered concentration of $\mathrm{Mg}^{2+}$ at the active site of the exonuclease may cause enhanced nuclease resistance. On the other hand, $2^{\prime}$-O-MTE is a soft-base, and may not effectively coordinate $\mathrm{Mg}^{2+}$ ions. This hypothesis requires further evaluation.

\section{CONCLUSIONS}

We have evaluated protein binding properties, RNA hybridization, and nuclease resistance of $2^{\prime}-O$-MTE modified oligonucleotides. The 2 - $O$-MTE modified phosphodiester oligonucleotides exhibited moderate protein binding, while 2'-O-MOE modified phosphodiester oligonucleotides showed poor protein binding. This property should improve biodistribution of $2^{\prime}$-O-MTE phosphodiester oligomers compared to $2^{\prime}-O$-MOE phosphodiester oligomers which are distributed only to the kidneys and are excreted fast. However, the $2^{\prime}$ $O$-MTE modified oligonucleotides as diesters were less stable to exonucleases compared with $2^{\prime}-O-M O E$ modified oligonucleotides as diesters. The improved protein binding and reduced nuclease resistance of $2^{\prime}$ - $O$-MTE oligonucleotides may be ascribed to the lack of a stable hydration network around the $2^{\prime}-O$-substituents. Such a network may not be available to $2^{\prime}$ - $O$-MTE oligonucleotides due to the lipophilic nature of the sulfur atom. The $2^{\prime}$-O-MTE modified oligonucleotides exhibit high binding affinity to RNA similar to $2^{\prime}-O$-MOE. The combination of high binding affinity to RNA, favorable protein binding properties and moderate nuclease resistance exhibited by this phosphodiester-based analogue warrant further in vivo pharmacokinetic and biodistribution evaluations of 2 - $O$-MTE modified antisense oligomers.

\section{ACKNOWLEDGMENT}

We want to thank Stan Crooke for initiating the Oligonucleotide-Protein Binding study at Isis. We thank Dr. Valentina Tereshko for help with data collection and Nancy Meskan for her assistance in preparing this manuscript. We are grateful to Professor M. E. Jung (UCLA) for helpful discussions and valuable comments relating to synthesis of the novel nucleoside precursors.

\section{REFERENCES}

1. Martin, P. (1995) Helv. Chim. Acta 78, 486-504.

2. Manoharan, M. (1999) Biochim. Biophys. Acta 1489, 117-130.

3. Cummins, L. L., Owens, S. R., Risen, L. M., Lesnik, E. A., Freier,
S. M., McGee, D., Guinosso, C. J., and Cook, P. D. (1995) Nucleic Acids Res. 23, 2019-24.

4. Crooke, S. T. (1998) Handb. Exp. Pharmacol. 131, 1-50.

5. Phillips, M. I. (2000) Methods Enzymol. 313.

6. Crooke, S. T., and LeBleu, B. (1993) Antisense Research and Applications, CRC Press Inc., Boca Raton, Florida.

7. De Mesmaeker, A., Haener, R., Martin, P., and Moser, H. E. (1995) Acc. Chem. Res. 28, 366-374.

8. Crooke, R. M., Graham, M. J., Martin, M. J., Lemonidis, K. M., Wyrzykiewiecz, T., and Cummins, L. L. (2000) J. Pharmacol. Exp. Ther. 292, 140-149.

9. Spitzer, S., and Eckstein, F. (1988) Nucleic Acids Res. 16, 11691704.

10. Gao, W. Y., Han, F. S., Storm, C., Egan, W., and Cheng, Y. C. (1992) Mol. Pharmacol. 41, 223-229.

11. Graham, M. J., Crooke, S. T., Monteith, D. K., Cooper, S. R., Lemonidis, K. M., Stecker, K. K., Martin, M. J., and Crooke, R. M. (1998) J. Pharmacol. Exp. Ther. 286, 447-458.

12. Geary, R. S., Watanabe, T. A., Truong, L., Freier, S., Lesnik, E. A., Sioufi, N. B., Sasmor, H., Manoharan, M., and Levin, A. A. (2001) J. Pharmacol. Exp. Ther. 296, 890-897.

13. Kumar, P., Sharma, A. K., Sharma, P., Garg, B. S., and Gupta, K. C. (1996) Nucleosides Nucleotides 15, 879-88.

14. Bayer, E., Bleicher, K., and Maier, M. (1995) Z. Naturforsch., B: Chem. Sci. 50, 1096-1100.

15. Manoharan, M., Tivel, K. L., Ross, B., and Cook, P. D. (1994) Gene 149, 147-156.

16. Kuznetsov, A. N., Gyul'khandanyan, G. V., and Ebert, B. (1977) Mol. Biol. (Moscow) 11, 1057-64.

17. Zini, R., Barre, J., Bree, F., Tillement, J. P., and Sebille, B. (1981) J. Chromatogr. 216, 191-8.

18. Otwinowski, Z., and Minor, W. (1997) Methods Enzymol. 276, 307-326.

19. Navaza, J. (1994) Acta Crystallogr., Sect. A: Found. Crystallogr. A50, 157-163.

20. Brunger, A. T., Adams, P. D., Clore, G. M., DeLano, W. L., Gros, P., Grosse-Kunstleve, R. W., Jiang, J.-S., Kuszewski, J., Nilges, M., Pannu, N. S., Read, R. J., Rice, L. M., Simonson, T., and Warren, G. L. (1998) in Acta Crystallogr., Sect. D: Biol. Crystallogr., 905-921.

21. Sheldrick, G. M., and Schneider, T. R. (1997) Methods Enzymol. 277, 319-343.

22. Fraser, A. S., Kawasaki, A. M., Jung, M. E., and Manoharan, M. (2000) Tetrahedron Lett. 41, 1523-1526.

23. Freier, S. M., and Altmann, K. H. (1997) The 2'-deoxyphosphorothioates cause $-0.8{ }^{\circ} \mathrm{C} /$ modification in RNA hybridization compared to DNA, Nucleic Acids Res 25, 4429-43.

24. Wolfe, S. (1972) Acc. Chem. Res. 5, 102-111.

25. Teplova, M., Minasov, G., Tereshko, V., Inamati, G. B., Cook, P. D., Manoharan, M., and Egli, M. (1999) Nat. Struct. Biol. 6, 535-539.

26. Bruin, G. J. M., Boernsen, K. O., Huesken, D., Gassmann, E., Widmer, H. M., and Paulus, A. (1995) J. Chromatogr., A 709, $181-95$.

27. Tereshko, V., Portmann, S., Tay, E. C., Martin, P., Natt, F., Altmann, K. H., and Egli, M. (1998) Biochemistry 37, 1062610634.

BI020264T 